\title{
Pengaruh Standarisasi ISO 9001: 2008 dan Budaya Organisasi terhadap Kinerja Karyawan pada PT. Sumberdaya Dian Mandiri
}

\author{
Laras Dwi Hartini \\ STIE Muhammadiyah Jakarta \\ Noor Indah Rahmawati \\ STIE Muhammadiyah Jakarta
}

\begin{abstract}
Abstrak
Kurangnya kesadaran karyawan mengenai pentingnya standardisasi ISO terutama ISO 9001:2008 sebagai pendukung kualitas perusahaan, kurangnya efektifitas penerapan standardisasi ISO 9001:2008, kinerja karyawan tidak maksimal dengan datang tidak sesuai dengan jam kerja sehingga pekerjaan tidak selesai pada waktu yang telah ditentukan menjadi masalah dalam proses pencapaian tujuan perusahaan. Penelitian ini bertujuan untuk mengetahui seberapa besar pengaruh standardisasi ISO 9001: 2008 terhadap kinerja karyawan, pengaruh budaya organisasi terhadap kinerja karyawan dan pengaruh standarisasi ISO 9001: 2008 dan budaya organisasi terhadap kinerja karyawan secara simultan.

Analisis data dalam penelitian ini menggunakan metode SPSS versi.17 untuk mengetahui hubungan antar variabel, dengan menggunakan regresi berganda dan analisis korelasi serta pengujian hipotesis menggunakan uji t dan uji F.

Penelitian ini menunjukkan pengaruh positif antara standarisasi ISO 9001: 2008 (X1) terhadap kinerja karyawan (Y) dengan Thitung 3,056 > Ttabel 1,989 dan nilai probabilitas 0,003. Sedangkan untuk variabel (X2) budaya organisasi terhadap kinerja karyawan (Y) hasil yang diperoleh -1,241 <dari 1.989 dengan nilai probabilitas 0.218 berarti tidak ada pengaruh antara variabel (X2) budaya organisasi terhadap kinerja karyawan (Y). Untuk hasil hipotesis dengan menggunakan uji f diperoleh hasil bahwa kinerja karyawan dipengaruhi oleh standarisasi ISO 9001: 2008 dan budaya organisasi secara bersamaan sebesar 10,9\%. Pengujian hipotesis menunjukkan pengaruh antara standarisasi ISO 9001: 2008 dan budaya organisasi secara simultan terhadap kinerja karyawan.

Oleh karena itu, untuk meningkatkan kinerja karyawan, perusahaan perlu mengadakan pelatihan ISO 9001: 2008 secara merata kepada semua karyawan sehingga pemahaman karyawan lebih luas tentang pentingnya standardisasi ISO 9001: 2008, penerapan budaya organisasi semakin ditingkatkan untuk benar-benar meresap dan karyawan maumemahami makna dari budaya organisasi itu sendiri.

Kata Kunci: Standarisasi ISO 9001: 2008, budaya organisasi, kinerja karyawan.
\end{abstract}

\section{PENDAHULUAN}

Dalam era global, persaingan menjadi sema- kin tajam.Perusahaan pada masa lalu hanya bersaing pada tingkat regional dan nasio- nal, pada masa sekarang harus menghadapi persaingan global. Hanya perusahaan yang dapat menghasilkan kualitas barang atau jasa yang sesuai dengan tuntutan pelanggan yang dapat memenangkan persaingan (Nasution, 2015: 17).

Dewasa ini terjadi perubahan pandangan mengenai kualitas. Suatu produk yang berkua- litas tidak hanya merupakan produk dengan performance yang baik tetapi juga harus memenuhi kriteria kepuasan konsumen.Hal ini merupakan faktor penting bagi perusahaan terutama dalam persaingan bisnis yang begitu ketat (Kiswanto, 2007:1).

Pesatnya perkembangan ilmu pengetahu- an dan teknologi menciptakan struktur baru, yaitu stuktur global.Kemajuan ilmu pengeta- huan dan teknologi yang disertai dengan semakin kencangnya arus globalisasi dunia membawa dampak tersendiri.Sumber daya manusia (SDM) merupakan salah satu faktor kunci dalam persaingan global, yaitu bagai- mana menciptakan SDM yang berkualitas dan memiliki keterampilan serta berdaya saing tinggi untuk menghadapi era global saat ini (Eko Supriyadi, 2012:1). 
Dalam persaingan yang semakin tajam dimana perilaku pasar telah berubah dari buyer - market menjadi seller - market, perusahaan yang tidak dapat memenuhi tuntutan pasar/konsumen akan tergeser dari dunia perdagangan. Untuk dapat menghadapi situasi seperti ini perusahaan perlu melakukan segala daya dan upaya guna meningkatkan produktifitas kerja karyawan maupun mutu barang atau jasa yang dihasilkan.Penyebab produktifitas karyawan disebabkan oleh kurangnya memiliki keterampilan (skil), kurangnya sarana penunjang, tingkat kesehatan dan gizi karyawan yang kurang diperhatikan sehingga karyawan mudah sakit, rendahnya tingkat upah dan tidak adanya pemberian insentif kepada karyawan yang berprestasi baik. (Rivai dan Sagala 2013:406)

Terlepas dari kecenderungan perilaku global seperti yang disebutkan di atas, lingkungan tempat sekelompok orang tinggal, dibesarkan dan bergaul dengan sesama dalam kurun waktu yang relatif lama tetap saja menjadi faktor penting yang mempengaruhi cara pandang, cara berpikir dan cara bertindak mereka. Begitu kuatnya pengaruh lingkungan setempat menyebabkan fenomena perilaku global sepertinya hanya bersifat artifisial. Artinya, dibalik fenomena perilaku global tersebut, masing-masing kelompok masya- rakat sesungguhnya tetap mempunyai karakter dan identitas diri yang membedakan satu kelompok masyarakat dengan kelompok masyarakat lainnya.Sehingga setiap kelompok mempunyai budaya yang berbeda-beda. (Sobirin, 2009:47)

Scein mendefinisikan budaya organisasi sebagai patern of bassic assumtions invented, discovered, or developed - by a given group as it learns to cope with a problem of external adaptation and internal integration that has worked well enough to be considered perceive, think, and feel in relation to those problem. Artinya budaya merupakan pola asumsi- asumsi dasar diciptakan, ditemukan, atau dikembangkan oleh suatu kelompok dalam belajar mengatasi masalah-masalah adaptasi eksternal dan integrasi internal, yang telah berhasil baik untuk dijadikan cara meman- dang, berpikir, dan merasa terhadap masalah tersebut. (Sudaryono, 2014:11)

Manusia sebagai makhluk sosial pada dasarnya mempunyai sifat untuk bersosialisasi, bekerja sama, dan membutuhkan keberadaan manusia lainnya. Untuk itu keberadaan sebuah organisasi sangat diperlukan sebagai suatu wadah yang dapat menghimpun atau mempermudah manusia dalam bersosialisasi dan bekerja sama. Organisasi merupakan suatu sarana yang beranggotakan orang-orang yang bekerja sama untuk mencapai tujuan bersama. (Wirawan dalam Yoga Pratama, 2012:1)

Dalam mempertahankan dan mengelola organisasi agar mampu bertahan hidup, peran sumber daya manusia mempunyai kedudukan yang sentral.Hal ini didasari oleh suatu pemikiran bahwa sumber daya manusia sebagai salah satu faktor produksi merupakan unsur utama dalam menciptakan peluang bisnis dalam berbagai kesempatan.Untuk meningkatkan perannya sebagai salah satu faktor produksi dalam perusahaan atau organisasi, maka SDM harus memiliki motivasi berprestasi karena salah satu karakteristik yang mempengaruhi prestasi kerja SDM adalah motivasi prestasi itu sendiri. (Dalimunte,2009:1)

Penelitian yang dilakukan oleh Purba adal pada tahun 2014 tentang analisis pengaruh sistem manajemen mutu ISO 9001: 2008 terhadap kinerja karyawan di PT. X dengan hasil menunjukkan bahwa Sistem Manajemen Mutu ISO 9001:2008 berpengaruh terhadap kinerja karyawan.

Penelitian yang dilakukan oleh Juana ad al pada tahun 2016 dengan judul Pengaruh Implementasi Sistem Manajemen Mutu ISO 9001: 2008 Terhadap Kinerja Pegawai dengan Mediasi Kepuasan Kerja, menunjukkan hasil bahwa implementasi ISO 9001: 2008 berpengaruh positif dan signifikan terhadap keputusan kerja dan kinerja pegawai dan kepuasan kerja berpengaruh positif dan signifikan terhadap kinerja pegawai. Kepuasan kerja pegawai merupakan variabel mediasi.

Kajian diatas sangat sesuai dengan kon- disi kerja pada PT. Sumberdaya Dian Mandiri. Banyaknya klienklien dari perusahaan besar menjadi tuntutan bagi PT. Sumberdaya Dian Mandiri untuk menunjukan kualitas perusahaan khususnya dibidang pelayanan jasa. Permasalahan tersebut akan menjadi kendala dalam proses pencapaian tujuan per- usahaan. Ditambah lagi dengan kurangnya kesadaran karyawan mengenai pentingnya standarisasi ISO khususnya ISO 9001:2008 sebagai penunjang kualitas perusahaan. Karyawan selalu memusatkan pekerjaan yang berkaitan dengan ISO pada saat akan diaudit, kurang efektifnya penerapan 
standarisasi ISO 9001:2008 seperti belum berjalannya perbaik- an berkesinambungan contohnya sistem program kerja yang belum selesai dibuat, kinerja karyawan yang belum maksimal dengan datang tidak sesuai dengan jam kerja sehingga pekerjaan tidak selesai pada waktu yang telah ditentukan. Dari uraian diatas maka peneliti tertarik untuk meneliti pengaruh standarisasi ISO 9001:2008 dan budaya organisasi terhadap kinerja karyawan.

Oleh karena itu peneliti mengambil judul "Pengaruh Standarisasi ISO 9001:2008 Dan Budaya Organisasi Terhadap Kinerja Karyawan Pada PT. Sumberdaya Dian Mandiri ”.

\section{Perumusan Masalah}

Berdasarkan identifikasi masalah dan batasan masalah yang telah diuraikan diatas, maka dapat dirumuskan masalahnya sebagai berikut:

a. Apakah terdapat pengaruh antara standari- sasi ISO 9001:2008 terhadap kinerja ka- ryawan pada PT. Sumberdaya Dian Man- diri?

b. Apakah terdapat pengaruh antara budaya organisasi terhadap kinerja karyawan pada PT. Sumberdaya Dian Mandiri?

c. Apakah terdapat pengaruh secara bersama- sama antara standarisasi ISO 9001:2008 dan budaya organisasi terhadap kinerja karyawan?

\section{Tujuan Penelitian}

Tujuan penelitian ini dilakukan adalah:

a. Untuk mengetahui pengaruh standarisasi ISO 9001:2008 terhadap kinerja karyawan pada PT. Sumberdaya Dian Mandiri.

b. Untuk mengetahui pengaruh budaya organisasi terhadap kinerja karyawanpada PT. Sumberdaya Dian Mandiri.

c. Untuk mengetahui pengaruh secara bersama-sama antara standarisasi ISO 9001:2008 dan budaya organisasi terhadap kinerja karyawanpada PT. Sumberdaya Dian Mandiri.

\section{Manfaat Penelitian}

\section{a. Bagi Peneliti}

Untuk mengembangkan ilmu pengetahuan dibidang manajemen khususnya tentang standarisasi ISO 9001: 2008, budaya organisasi dan kinerja karyawan.

b. Bagi Perusahaan

Dapat dipakai sebagai masukan yang posi- tif dalam rangka meningkatkan kinerja karyawan melalui ISO 9001: 2008 dan budaya organisasi.

\section{LANDASAN TEORI}

\section{Manajemen Sumber Daya Manusia}

"Manajemen sumber daya manusia merupakan bagian dari ilmu manajemen yang memfokuskan perhatiannya pada pengaturan peranan sumber daya manusia dalam kegiatan suatu organisasi”. (Tjuju Yuniarsih dan Suwanto, 2009:1)

Hasibuan (2013:2) menungkapkan penda- patnya mengenai pengertian manajemen sum- ber daya manusia yaitu :

"Manajemen sumber daya manusia suatu pengelolaan dan pendayagunaan sumber daya yang ada pada individu (pegawai).Pengelolaan dan pendayagunaan tersebut dikembangkan secara maksimal didalam dunia kerja untuk mencapai tujuan organisasi dan pengembangan individu pegawai”.

\section{Standarisasi ISO 9001:2008 Pengertian Standarisasi}

Standar bukan kata asli dari bahasa Indonesia, melainkan merupakan alih bahasa dari suku kata Inggris "standard". Dari kata dasar standard dibentuk kata standardization, yang diterjemahkan ke dalam bahasa 
Indonesia menjadi standardisasi. Kata standard sendiri merupakan terjemahan dari bahasa Perancis norme dan etalon. Istilah norme dapat didefinisikan sebagai standar dalam bentuk dokumen, sedangkan etalon adalah standar dalam bentuk pengukuran.Untuk membedakan istilah standar tersebut, maka istilah standard diberi makna norme, sedangkan etalon dalam bahasa Inggris diartikan measurement standard. (Badan Standarisasi Nasional, 2014:12)

Standar adalah spesifikasi teknis atau sesuatu yang dibakukan termasuk tata cara dan metode yang disusun berdasarkan konsensus semua pihak yang terkait dengan memperhatikan syarat-syarat keselamatan, keamanan, kesehatan, lingkungan hidup, perkembangan ilmu pengetahuan dan teknologi, serta pengalaman, perkembangan masa kini dan masa yang akan datang untuk memperoleh manfaat yang sebesar-besarnya. Dari kata standar maka munculah kata standarisasi yang artinya artinya proses merumuskan, menetapkan, menerapkan, dan merevisi standar, yang dilaksanakan secara tertib melalui kerjasama dengan semua pihak yang berkepentingan (Peraturan Pemerintah Republik Indonesia No. 102 Tahun 2000).

"Sertifikasi ISO atau International Organitation For Standarization merupakan badan standarisasi non pemerintah yang bertujuan untuk meningkatkan citra perusahaan, kinerja, daya saing, memperbaiki manajemen perusahaan dengan menerapkan perencanaan, pelaksanaan, pengukuran, dan tindakan perbaikan untuk mengurangi segala resiko. Dengan demikian standarisasi dapat menyelaraskan berbagai produk atau jasa layanan terhadap keinginan para konsumen". (Berata, 2014:26)

Menurut Rangkuti (2013:12) perkembangan ISO dari 9001:2000 menjadi 9001: 2008 adalah "Sebagai bentuk penyempurnaan terhadap ISO 9001:2000. Perbedaan antara ISO 9001:2000 dan ISO 9001: 2008 adalah pada efektifitas proses yang dilaksanakan pada organisasi tersebut. Artinya, tindakan proses corrective dan preventive yang dilakukan harus secara efektif memiliki dampak positif terhadap perubahan proses yang terjadi dalam organisasi tersebut. Untuk itu pada ISO 9001:2008 lebih berfokus pada efektivitas proses perbaikan secara terus menerus untuk meningkatkan kepuasan pelanggan dengan mengadopsi prinsip manajemen plan, do, check, action (PDCA)".

\section{Prinsip Manajemen Mutu ISO}

Prinsip manajemen mutu merupakan metoda bagaimana cara memimpin, mengatur, dan mengendalikan suatu organisasi atau Badan Usaha. Dengan prinsip-prinsip manajemen itu standar manajemen mutu dapat dioperasikan secara konsisten, sistemastis, dan transparan. Artinya prinsip-prinsip ini dipahami untuk mengendalikan manajemen mutu agar dapat mewujudkan keberhasilan di Badan Usaha. Agar proses implementasi ISO 9001:2008 dapat berjalan dengan baik, setiap organisasi perusahaan yang menerapkan ISO 9001:2008 perlu menerapkan delapan prinsip manajemen mutu yang bertujuan untuk mengimprovisasi kinerja sistem agar proses yang berlangsung sesuai dengan perkembangan efektifitas kelanjutan. Kedelapan prinsip tersebut menurut Sunu P (dalam Indriana Lestari, 2012:20) adalah sebagai berikut:

a. Fokus pada pelanggan Kepemimpinan

b. Keterlibatan semua orang Pendekatan proses Pendekatan sistem ke manajemen

c. Perbaikan berkelanjutan Pendekatan fakta sebagai dasar pengambilan keputusan

d. Kerjasama yang saling menguntungkan dengan pemasok.

Tujuan dan Manfaat Standarisasi ISO Tujuan penerapan standar khususnya ISO- 9001 menurut Suryatama (2014:11) adalah sebagai berikut :

a. Memenuhi persyaratan pelanggan.

b. Memenuhi peraturan-peraturan yang ber- laku berkaitan dengan bisnis pertambangan, baik secara nasional/internasional.

c. Mendapatkan pedoman kerja yang standar dalam pelaksanaan proses operasi konsultansi manajemen dan penempatan tenaga ahli.

d. Memelihara dan meningkatkan citra perusahaan. 
e. Mengantisipasi persaingan dengan perusa- haan sejenis.

f. Memenuhi persyaratan tender/kontrak suatu pekerjaan/proyek.

\section{Pengertian Budaya Organisasi}

Budaya organisasi adalah seperangkat asumsi atau sistem keyakinan, nilai-nilai dan norma yang dikembangkan dalam organisasi yang dijadikan pedomaan tingkah laku bagi anggota-anggotanya untuk mengatasi masalah adaptasi eksternal dan internal. Mangkunegara (dalam Prima Nugraha S Sinaga, 2010)

Karakteristik budaya organisasi menurut Stephen P Robin dalam Asfar Halim Dalimunthe (2009:20) adalah sebagai berikut : inisiatif individual, toleransi terhadap tindakan berisiko, pengarahan, integrasi, dukungan manaje- men, kontrol, identitas, sistem imbalan, toleransi terhadap konflik dan pola komunikasi.

\section{Kinerja Karyawan}

"Kinerja adalah keberhasilan dalam me- laksanakan tugas serta pencapaian tujuan yang telah ditetapkan oleh suatu organisasi berdasarkan sasaran, standar dan kriteria yang telah ditetapkan”. Fikri Amrullah (2015:69)

\section{METODE}

\section{Objek Penelitian}

Objek penelitian disini dimaksudkan adalah yang berkaitan dengan variabel yang diteliti. Dalam penelitian ini yang menjadi variabel bebasnya adalah standarisasi ISO (X1) 9001: 2008 dan budaya organisasi (X2) sedangkan variabel terikatnya adalah kinerja karyawan (Y).

\section{Populasi dan Sampel}

Dalam penelitian ini, populasi di PT. Dian Mandiri Resources sebanyak 108 orang. De- ngan populasi seperti itu, pengambilan sampel dilakukan dengan rumus Slovin (Umar, 2012:112) adalah sebagai berikut:

$$
n=\frac{N}{1+N_{e}^{2}}
$$

\section{Keterangan:}

$\mathrm{n}=$ Jumlah sampel $\mathrm{N}=$ Populasi

$\mathrm{e}=$ Selisih atau kesalahan yang direncanakan

Jumlah sampel dalam penelitian ini sebanyak 108 karyawan, tingkat kesalahan 5\% adalah sebagai berikut:

$$
\begin{aligned}
& n=\frac{108}{1+108(0,05)^{2}} \\
& n=85.03
\end{aligned}
$$

Jadi jumlah sampel yang digunakan dalam penelitian ini sebanyak 85 sampel.

\section{Kerangka Pikir}

Penelitian yang dilakukan ini akan mengungkap pengaruh Standarisasi ISO 9001:2008 dan Budaya Organisasi Terhadap Kinerja Karyawan. Berdasarkan kajian teori dan penelitian-penelitian terdahulu yang dipaparkan dalam Bab II, dengan menggunakan standarisasi ISO 9001:2008 dan budaya organisasi sebagai 
variabel bebas atau independen dan kinerja karyawan sebagai variabel terikat atau dependen, secara sistematis dapat digambarkan sebagai berikut:

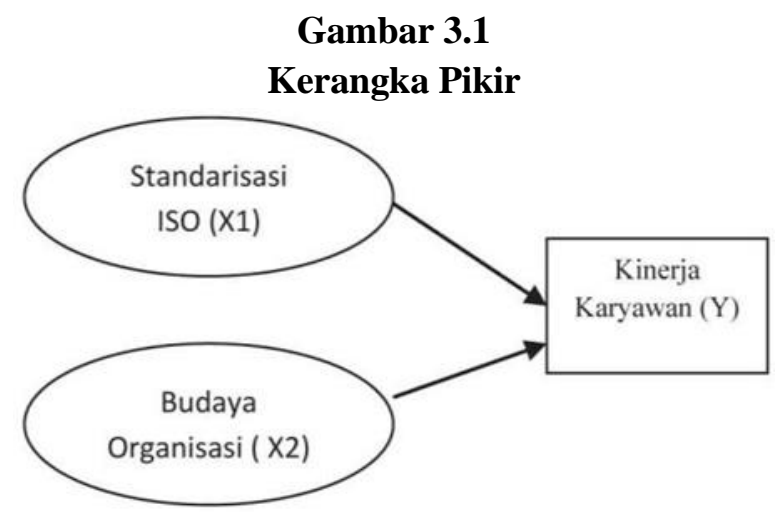

\section{Hipotesis}

Hipotesis merupakan jawaban sementara ter- hadap rumusan masalah penelitian, di mana rumusan masalah penelitian telah dinyatakan dalam bentuk kalimat pertanyaan.

Analisis Hipotesis dan Metode Pengujian Analisis data dalam penelitian ini menggunakan SPSS versi 17.0

\section{Pengujian :}

a. Uji Validitas

b. Uji Reliabilitas

c. Analisis Regresi Berganda

d. Analisis Korelasi Berganda

e. Koefisin korelasi

f. Koefisin determinasi berganda

g. Uji Hipotesis dengan Menggunakan statistik uji t

h. Uji Hipotesis dengan Menggunakan statistik uji $\mathrm{F}$

\section{HASIL PENELITIAN}

\section{Deskripsi Data}

Responden yang menjadi sampel dalam pe- nelitian ini, sebagaimana yang telah dikemu- kakan sebelumnya adalah seluruh karyawan PT. Sumberdaya Dian Mandiri, suatu usaha yang bergerak dibidang jasa konsultan dan outsourching.Kuesioner penelitian disebar sebanyak 85 kuesioner kepada para responden target. Dari 85 kuesioner yang disampaikan kepada responden, semua kuesioner dikembalikan dan layak digunakan untuk analisis data selanjutnya, sehingga tingkat respon untuk penelitian ini adalah $100 \%$.Berikut ini adalah penjelasan mengenai karakteristik responden.

\section{Karakteristik Responden Berdasarkan Jenis Kelamin}

Karakteristik responden berdasarkan jenis kelamin dapat diihat pada tabel 4.1.

Berdasarkan tabel 4.1, dapat diketahui bahwa jumlah responden pria lebih banyak daripada responden wanita, yaitu sebanyak 43 orang $(50,6 \%)$, sedangkan sebanyak 42 orang $(49,4 \%)$ merupakan responden wanita. 
Tabel 4.1

Data Responden Berdasarkan Jenis Kelamin

\begin{tabular}{|l|l|l|}
\hline $\begin{array}{l}\text { Jenis } \\
\text { Kelamin }\end{array}$ & $\begin{array}{l}\text { Jumlah } \\
\text { Responden }\end{array}$ & $\begin{array}{l}\text { Persentase } \\
(\%)\end{array}$ \\
\hline Pria & 43 & $50,6 \%$ \\
\hline Wanita & 42 & $49,4 \%$ \\
\hline Jumlah & 85 & $100 \%$ \\
\hline
\end{tabular}

Sumber : Data Primer Diolah (Agustus 2017)

\section{Karakteristik Responden Berdasarkan Usia}

Karakteristik responden berdasarkan usia dapat dilihat pada tabel 4.2.

Tabel 4.2 Karakteristik Responden Berdasarkan Usia

\begin{tabular}{|c|c|c|}
\hline $\begin{array}{c}\text { Usia } \\
\text { Responden }\end{array}$ & $\begin{array}{c}\text { Jumlah } \\
\text { Responden }\end{array}$ & $\begin{array}{c}\text { Persentase } \\
(\%)\end{array}$ \\
\hline$<20$ & 2 & $2,4 \%$ \\
\hline $21-30$ & 50 & $58,8 \%$ \\
\hline $31-40$ & 22 & $25,9 \%$ \\
\hline$>40$ & 11 & $12,9 \%$ \\
\hline Jumlah & 85 & $100 \%$ \\
\hline
\end{tabular}

Sumber : Data Primer Diolah (Agustus 2017)

Berdasarkan tabel 4.2 diatas mengenai da- ta responden berdasarkan usia dapat diketahui bahwa responden yang berusia $<20$ tahun se- banyak 2 orang $(2,4 \%)$, responden yang ber- usia 21 - 30 tahun sebanyak 50 orang $(58,8 \%)$, responden yang berusia $31-40$ ta- hun sebanyak 22 orang $(25,9 \%)$, dan sisanya sebanyak 11 orang $(12,9 \%)$ adalah responden yang berusia $>40$ tahun.

\section{Karakteristik Responden Berdasarkan Tingkat Pendidikan}

Karakteristik responden berdasarkan ting- kat pendidikan dapat dilihat pada tabel 4.3.

Berdasarkan tabel 4.3 mengenai data res- ponden berdasarkan tingkat pendidikan dapat diketahui bahwa responden yang tingkat pen- didikannya SMU / SMK sebanyak 20 orang (23,5\%), tingkat Diploma 3 sebanyak 16 orang (18,8\%), Strata 1 sebanyak 48 orang (56,5\%), dan sisanya sebanyak 1 orang $(1,2 \%)$ dengan pendidikan Strata 2.

Tabel 4.3

Data Responden Berdasarkan Tingkat Pendidikan

\begin{tabular}{|c|c|c|}
\hline $\begin{array}{c}\text { Tingkat } \\
\text { Pendidikan }\end{array}$ & $\begin{array}{c}\text { Jumlah } \\
\text { Responden }\end{array}$ & $\begin{array}{c}\text { Persentase } \\
(\%)\end{array}$ \\
\hline SMU / SMK & 20 & $23,5 \%$ \\
\hline Diploma 3 & 16 & $18,8 \%$ \\
\hline Strata 1 & 48 & $56,5 \%$ \\
\hline Strata 2 & 1 & $1,2 \%$ \\
\hline Jumlah & 85 & $100 \%$ \\
\hline
\end{tabular}

Sumber: Data Primer Diolah (Agustus 2017) 


\section{Karakteristik Responden Berdarkan Masa Kerja Berdasarkan Masa Kerja}

Karakteristik responden berdasarkan masa kerja dapat dilihat pada tabel 4.4

Tabel 4.4

Data Responden Berdasarkan Masa Kerja

\begin{tabular}{|c|c|c|}
\hline $\begin{array}{c}\text { Masa } \\
\text { Kerja }\end{array}$ & $\begin{array}{c}\text { Jumlah } \\
\text { Responden }\end{array}$ & $\begin{array}{c}\text { Persentase } \\
(\%)\end{array}$ \\
\hline $1-5$ Tahun & 54 & $64 \%$ \\
\hline $6-10$ Tahun & 16 & $19 \%$ \\
\hline $11-15$ Tahun & 8 & $9 \%$ \\
\hline $16-20$ Tahun & 3 & $4 \%$ \\
\hline$>20$ Tahun & 4 & $5 \%$ \\
\hline Jumlah & 85 & $100 \%$ \\
\hline
\end{tabular}

Sumber: Data Primer Diolah (Agustus 2017)

Berdasarkan pada tabel 4.4, berdasarkan masa kerja dapat diketahui bahwa responden dengan masa kerja $1-5$ tahun sebanyak 54 orang (64\%), responden dengan masa kerja 11 - 15 tahun sebanyak 8 orang (9\%), responden dengan masa kerja 16 - 20 tahun sebanyak 3 orang (4\%), dan sebanyak 4 orang (5\%) respondeng dengan masa kerja > 20 tahun.

\section{Pembahasan Uji Validitas}

Syarat minimum untuk dinyatakan valid apa- bila korelasi setiap indikator tersebut besarnya

$>0.3$, jika salah satu indikator memiliki nilai

$<0,3$ maka indikator tersebut dinyatakan tidak valid dan harus dibuang (didrop) (Nurlaela Wati, 2011:84). Variabel Standarisasi ISO

9001:2008 diukur oleh indikator X1.1 - X.1.10, variabel Budaya Organisasi diukur oleh indikator X.2.1 X2.10, dan variabel Kinerja Karyawan diukur oleh indikator Y1 - Y10. Hasil output uji validasi variabel pada SPSS adalah sebagai berikut :

Tabel 4.5

Out Put Uji Validitas X1

Item-Total Statistics

\begin{tabular}{|c|c|c|c|c|c|}
\hline & $\begin{array}{l}\text { Scale Mean if } \\
\text { item Deleted }\end{array}$ & $\begin{array}{c}\text { Scale } \\
\text { Variance if } \\
\text { Item Deleted }\end{array}$ & $\begin{array}{l}\text { Corrected } \\
\text { Item-Total } \\
\text { Correlation } \\
\end{array}$ & $\begin{array}{c}\text { Squared } \\
\text { Multiple } \\
\text { Correlation } \\
\end{array}$ & $\begin{array}{l}\text { Cronbach's } \\
\text { Alpha if item } \\
\text { Deleted }\end{array}$ \\
\hline Item01 & 67.04 & 207.701 & .691 & 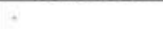 & .763 \\
\hline Item02 & 66.88 & 212.605 & .613 & . & .770 \\
\hline Item03 & 67.26 & 204.813 & .774 & . & .759 \\
\hline Item04 & 67.45 & 202.203 & .788 & . & .755 \\
\hline Item05 & 67.49 & 202.015 & 816 & . & .755 \\
\hline Item06 & 67.88 & 197.653 & .799 & . & .749 \\
\hline Item07 & 67.29 & 206.853 & .664 & . & .763 \\
\hline Item08 & 67.41 & 201.959 & .787 & . & .755 \\
\hline Item09 & 67.72 & 200.681 & .820 & . & .753 \\
\hline Item10 & 67.74 & 202.242 & .750 & & .756 \\
\hline$\times 1$ & 35.48 & 56.372 & 1.000 & . & .927 \\
\hline
\end{tabular}

Sumber : Hasil diolah SPSS versi.17

Berdasarkan output uji validitas seperti pada gambar di atas menunjukan nilai indika- tornya lebih dari 0,3 , artinya semua item per- nyataan pada variabel X1 dinyatakan valid. 
Tabel 4.6

Out Put Uji Validitas X2

\begin{tabular}{|l|r|r|r|r|r|}
\hline \multicolumn{7}{|c|}{ Item-Total Statistics } \\
\hline & $\begin{array}{c}\text { Scale Mean if } \\
\text { Item Deleled }\end{array}$ & $\begin{array}{c}\text { Scale } \\
\text { Variance if } \\
\text { Item Deleted }\end{array}$ & $\begin{array}{c}\text { Corrected } \\
\text { Item-Total } \\
\text { Correlation }\end{array}$ & $\begin{array}{c}\text { Squared } \\
\text { Multiple } \\
\text { Correlation }\end{array}$ & $\begin{array}{c}\text { Cronbach's } \\
\text { Alpha if Item } \\
\text { Deleted }\end{array}$ \\
\hline Item01 & 69.73 & 42.200 & .508 & & .682 \\
Item02 & 70.31 & 42.310 & .463 & & .684 \\
Item03 & 69.91 & 42.991 & .477 & & .687 \\
Item04 & 69.82 & 43.647 & .493 & & .690 \\
Item05 & 70.45 & 44.583 & .171 & & .710 \\
Item06 & 69.69 & 42.858 & .531 & & .685 \\
Item07 & 70.54 & 40.489 & .502 & .674 \\
Item08 & 69.56 & 42.701 & .516 &. & .684 \\
Item09 & 70.62 & 43.380 & .268 & & .700 \\
Item10 & 70.35 & 44.136 & .282 & & .640 \\
X2 & 36.89 & 11.786 & 1.000 & & .641 \\
\hline
\end{tabular}

Sumber : Hasil diolah SPSS versi.17

Berdasarkan output uji validitas pada variabel X2, masih terdapat nilai indikator di bawah 0,3. Karena masih memiliki nilai yang rendah, maka indikator-indikator dibawah 0,3 harus didrop. Pada output indikator di atas X.2.5, X.2.9, dan X.2.10 nilainya masih di bawah 0,3 sehingga indikator tersebut harus didrop.

Berdasarkan output diatas merupakan hasil uji validitas setelah direvisi, maka uji validitas tersebut sudah diatas 0,3 dan dinyatakan valid.

Tabel 4.7

Output Uji Validitas X2 Revisi

\begin{tabular}{|c|c|c|c|c|c|}
\hline \multicolumn{6}{|c|}{ Item-Iotal Statistics } \\
\hline & $\begin{array}{l}\text { Scale Mean if } \\
\text { tiem }\end{array}$ & $\begin{array}{l}\text { Scale } \\
\text { variance if }\end{array}$ & $\begin{array}{l}\text { Corrected } \\
\text { trem-Totala } \\
\text { corregation }\end{array}$ & $\begin{array}{c}\text { Squared } \\
\text { Multiple } \\
\text { Cortelion }\end{array}$ & $\begin{array}{l}\text { Cronbach's } \\
\text { Alpha if ittem }\end{array}$ \\
\hline Item01 & 49.85 & 28.869 & .600 & . & .719 \\
\hline Item02 & 50.42 & 29.128 & .525 & & .725 \\
\hline Item03 & 50.02 & 29.809 & .534 & & .729 \\
\hline Item04 & 49.94 & 30.389 & .558 & & .733 \\
\hline Item06 & 49.81 & 29.726 & .589 & & .727 \\
\hline Item 07 & 50.66 & 27.632 & .547 & & .715 \\
\hline Item08 & 49.68 & 29.791 & .537 & & .729 \\
\hline$x_{2}$ & 26.95 & 8.426 & 1.000 & & .736 \\
\hline
\end{tabular}

Tabel 4.8 Output Uji Validitas Y

\begin{tabular}{|c|c|c|c|c|c|}
\hline \multicolumn{6}{|c|}{ Item-Total Statistics } \\
\hline & $\begin{array}{l}\text { Scale Mean if } \\
\text { Item Deleted }\end{array}$ & $\begin{array}{c}\text { Scale } \\
\text { Variance if } \\
\text { Item Deleteted }\end{array}$ & $\begin{array}{l}\text { Corrected } \\
\text { Item-Total } \\
\text { Correlation }\end{array}$ & $\begin{array}{c}\text { Squared } \\
\text { Multiples } \\
\text { Correlation }\end{array}$ & $\begin{array}{c}\text { Cronbach's } \\
\text { Alpha if Item } \\
\text { Deleted }\end{array}$ \\
\hline Item01 & 63.99 & 83.583 & .584 & & .740 \\
\hline Item02 & 63.76 & 88.301 & .233 & & .759 \\
\hline Item03 & 64.14 & 83.718 & .558 & & .741 \\
\hline Item04 & 64.04 & 81.987 & .701 & & .733 \\
\hline Item05 & 63.99 & 80.678 & .717 & & .729 \\
\hline Itemo6 & 64.13 & 79.590 & .663 & & .727 \\
\hline Item07 & 64.16 & 84.734 & .510 & & .745 \\
\hline Item08 & 64.13 & 81.328 & .682 & & .732 \\
\hline Item09 & 64.31 & 81.786 & .626 & & .734 \\
\hline Item10 & 64.44 & 81.939 & .632 & & .735 \\
\hline & 33.74 & 22.837 & 1.000 & & .843 \\
\hline
\end{tabular}

sumber : Hasil diolah SPSS versi.17

Berdasarkan output uji validitas di atas masih terdapat nilai indikator dibawah 0,3 yaitu pada item Y.2, sehingga indikator pernyataan tersebut harus didrop.

Tabel 4.9

Output Uji Validitas Y Revisi

\begin{tabular}{|l|r|r|r|r|r|}
\hline & $\begin{array}{c}\text { Scale Mean if } \\
\text { Item Deleted }\end{array}$ & $\begin{array}{c}\text { Scale } \\
\text { Variance if } \\
\text { Item Deleted }\end{array}$ & $\begin{array}{c}\text { Corrected } \\
\text { ltem- Total } \\
\text { Correlation }\end{array}$ & $\begin{array}{c}\text { Squared } \\
\text { Multiple } \\
\text { Correlation }\end{array}$ & $\begin{array}{c}\text { Cronbach's } \\
\text { Alpha ifftem } \\
\text { Deleted }\end{array}$ \\
\hline Item01 & 56.55 & 79.083 & .530 & & .753 \\
Item03 & 56.71 & 78.948 & .528 & & .752 \\
Item04 & 56.60 & 76.719 & .718 & & .741 \\
Item05 & 56.55 & 75.369 & .739 & & .736 \\
Item06 & 56.69 & 74.167 & .691 & & .734 \\
Item07 & 56.73 & 79.652 & .503 & & .755 \\
Item08 & 56.69 & 76.191 & .688 & & .740 \\
Item09 & 56.87 & 76.400 & .650 & & .742 \\
Item10 & 57.00 & 76.595 & .654 & & .742 \\
Y & 30.02 & 21.499 & 1.000 & & .856 \\
\hline
\end{tabular}

Sumber : Hasil diolah SPSS versi.17

Berdasarkan output diatas merupakan hasil uji validitas setelah direvisi, maka uji validitas tersebut sudah diatas 0,3 dan dinyatakan valid. 


\section{Uji Reliabilitas}

Dalam penelitian, suatu variabel dikatakan cukup reliabilitas bila variabel tersebut mempunyai nilai cronbachs alpha lebih besar dari 0,7. (Nurlaela Wati, 2011:84) Berikut adalah hasil uji reliabiltas dari masing-masing variabel

Tabel 4.10

Uji Reliabilitas X1

Reliability Statistics

\begin{tabular}{|c|c|r|}
\hline $\begin{array}{c}\text { Cronbach's } \\
\text { Alpha }\end{array}$ & $\begin{array}{c}\text { Cronbach's } \\
\text { Alpha Based } \\
\text { on } \\
\text { Standardized } \\
\text { Items }\end{array}$ & N of Items \\
\hline .779 & .943 & 11 \\
\hline
\end{tabular}

Sumber : Hasil diolah SPSS versi.17

Tabel 4.11

Uji Reliabilitas X2

Reliability Statistics

\begin{tabular}{|c|c|c|}
\hline $\begin{array}{l}\text { Cronbach's } \\
\text { Alpha }\end{array}$ & $\begin{array}{c}\text { Cronbach's } \\
\text { Alpha Based } \\
\text { on } \\
\text { Standardized } \\
\text { Items } \\
\end{array}$ & $\mathrm{N}$ of ltems \\
\hline .752 & .834 & 8 \\
\hline
\end{tabular}

Sumber : Hasil diolah SPSS versi.17

Tabel 4.12 Uji Reliabilitas Y

Reliability Statistics

\begin{tabular}{|c|c|c|}
\hline $\begin{array}{l}\text { Cronbach's } \\
\text { Alpha }\end{array}$ & $\begin{array}{c}\text { Cronbach's } \\
\text { Alpha Based } \\
\text { on } \\
\text { Standardized } \\
\text { Items }\end{array}$ & $\mathrm{N}$ of Items \\
\hline .767 & .892 & 10 \\
\hline
\end{tabular}

Sumber : Hasil diolah SPSS versi.17

Berdasarkan hasil output reliabilitas di atas, dapat disimpulkan bahwa untuk variabel Standarisasi ISO 9001: 2008, Budaya Organisasi, dan Kinerja Karyawan memiliki cronbach's alpha diatas 0,7 sehingga dapat disimpulkan bahwa indikator-indikator yang digunakan pada masing-masing variabel mempunyai reabilitas yang baik atau mampu untuk mengukur konstruknya.

Tabel 4.13 Regresi Berganda

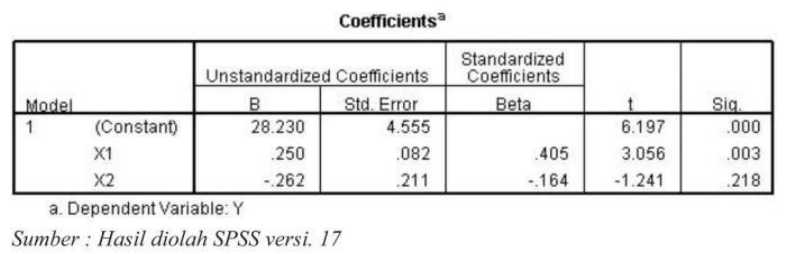

\section{Analisis Regresi Berganda}

Untuk mengetahui ada tidaknya pengaruh antara dua variabel bebas (X) yaitu standarisasi ISO 9001:2008 (X1) dan budaya organisasi (X2) dengan variabel tidak bebas (Y) yaitu kinerja karyawan, berdasarkan output diatas maka dinyatakan dalam persamaan sebagai berikut : 


$$
\mathrm{Y}=\mathrm{a}+\mathrm{b} 1 \mathrm{X} 1+\mathrm{b} 2 \mathrm{X} 2
$$

Maka

$$
\mathrm{Y}=28,230+0,250 \mathrm{ISO}-0,262 \mathrm{BO}
$$

Dari persamaan regresi berganda di atas diketahui nilai konstanta sebesar 28,230, artinya jika standarisasi ISO 9001:2008 dan budaya organisasi tidak diterapkan maka kinerja karyawan adalah sebesar 28,230. Nilai koefisien regresi standarisasi ISO (X1) sebasar 0,250 artinya setiap kenaikan X1 (standarisasi ISO diterapkan bertambah 1) maka kinerja karyawan akan meningkat sebesar 0,250 (ko- relasi positif).

Koefisien regresi X2 sebesar -0,262 artinya setiap kenaikan X2 (budaya organisasi bertambah 1) maka kinerja karyawan akan turun sebesar minus 0,262 (korelasi negatif).

Dari persamaan regresi berganda di atas bahwa variabel standarisasi ISO 9001: 2008 mempunyai pengaruh yang lebih besar terhadap kinerja karyawan.

\section{Analisis Korelasi Berganda}

TABEL 4.14 ANALISIS KORELASI

\begin{tabular}{|ll|r|r|r|}
\hline & & \multicolumn{1}{|c|}{ Correlations } \\
\hline Pearson Correlation & $Y$ & 1.000 & .303 & .085 \\
& $X 1$ & .303 & 1.000 & .616 \\
& $\times 2$ & .085 & .616 & 1.000 \\
\hline Sig. (1-tailed) & $Y$ & & .002 & .220 \\
& $\times 1$ & .002 & & .000 \\
& $X 2$ & .220 & .000 & \\
\hline N & $Y$ & 85 & 85 & 85 \\
& $X 1$ & 85 & 85 & 85 \\
& $X 2$ & 85 & 85 & 85 \\
\hline
\end{tabular}

Sumber : Hasil diolah SPSS versi.17

Nilai korelasi pada variabel standarisasi ISO 9001:2008 terhadap kinerja karyawan adalah sebesar 0,303.Artinya terdapat pe- ngaruh antara standarisasi ISO 9001:2008 de- ngan kinerja karyawan, dan hubungan antara kedua variabel tersebut searah dengan tingkat keeratannya dikatagorikan rendah.

Sedangkan korelasi variabel budaya orga- nisasi adalah sebesar 0,085.Artinya terdapat pengaruh antara budaya organisasi dengan kinerja karyawan, dan hubungan antara kedua variabel tersebut searah meskipun tingkat ke- eretannya sangat rendah.

Berdasarkan angka korelasi, variabel stan- darisasi ISO 9001:2008 lebih berpengaruh terhadap kinerja karyawan dibanding variabel budaya organisasi.

\section{Koefisien Korelasi dan Determinasi Berganda}

Tabel 4.14

Koefisien Korelasi dan Koefisien Determinasi

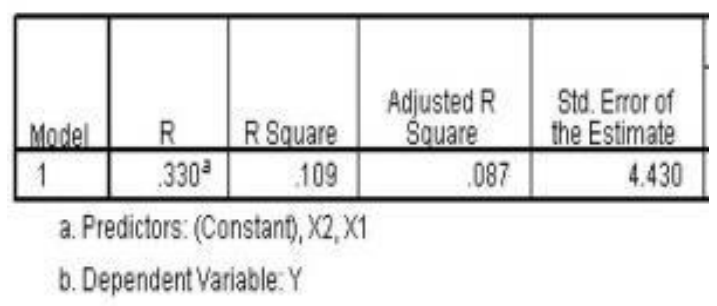

Sumber : Hasil dioleh SPSS versi. 17 
Sementara itu nilai korelasi secara simul- tan berdasarkan output diatas diperoleh $r$ sebesar 0,330 angka ini menggambarkan adanya korelasi yang positif dan signifikan antara variabel standarisasi ISO 9001:2008 dan budaya organisasi secara bersama-sama (simultan) terhadap kinerja karyawan. Dengan nilai $r=0,330$ berdasarkan pada tabel 3.6 pedoman interprestasi koefisien korelasi, pengaruh variabel standarisasi ISO 9001: 2008 dan budaya organisasi secara bersama-sama (simultan) terhadap kinerja karyawan dikategorikan rendah. Untuk nilai $\mathrm{r} 2$ (R Square) analisis simultannya adalah sebesar 0,109 atau sebesar 10,9\% kinerja karyawan dipengaruhi oleh variabel standarisasi ISO 9001:2008 dan budaya organisasi, dan sisanya sebesar $89,1 \%$ dipengaruhi oleh faktor lain.

\section{Uji Hipotesis Menggunakan Uji t}

Untuk menguji keberartian secara parsial pengaruh antara variabel standarisasi ISO 9001:2008 terhadap kinerja karyawan maka dilakukan uji hipotesis.

Rumusan hipotesisnya adalah :

$\mathrm{H} 0=$ diduga tidak terdapat pengaruh antara standarisasi ISO 9001:2008 terhadap kinerja karyawan.

$\mathrm{Ha}=$ diduga terdapat pengaruh antara standarisasi ISO 9001:2008 terhadap kinerja karyawan.

Taraf signifikansinya adalah 5\% keputusan menerima atau menolak hipotesis yang diajukan dilakukan dengan syarat sebagai berikut:

1) Jika Thitung $\leqslant$ Ttabel maka hipotesis nol (H0) diterima atau Ha ditolak. Artinya tidak terdapat pengaruh antara standarisasi ISO 9001:2008 terhadap kinerja karyawan.

2) Jika Thitung $\geqslant$ Ttabel maka hipotesis nol (H0) ditolak atau Ha diterima. Artinya terdapat pengaruh antara standarisasi ISO 9001: 2008 terhadap kinerja karyawan.

Tabel 4.16 Hipotesis Uji t

Coefficients $^{a}$

\begin{tabular}{|c|c|c|c|c|c|c|}
\hline \multirow[b]{2}{*}{ Madel } & & \multicolumn{2}{|c|}{ Unstandardized Coefficients } & \multirow{2}{*}{$\begin{array}{c}\begin{array}{c}\text { Standardized } \\
\text { Coefficients }\end{array} \\
\text { Beta }\end{array}$} & \multirow[b]{2}{*}{$t$} & \multirow[b]{2}{*}{ Sig. } \\
\hline & & $B$ & Std. Error & & & \\
\hline 1 & (Constant) & 28.230 & 4.555 & & 6.197 & .000 \\
\hline & $X_{1}$ & .250 & .082 & .405 & 3.056 & .003 \\
\hline & $x_{2}$ & -262 & .211 & -164 & -1.241 & .218 \\
\hline
\end{tabular}

Thitung yang diperoleh dari hasil output SPSS pada variabel X1 adalah 3,056 dan pada Ttabel nya adalah 1,989. Maka 3,056 > 1,989. Artinya Thitung lebih besar dari Ttabel sehingga hipotesis diterima, dengan nilai probabilitas pada kolom signifikan sebesar 0,003 jauh lebih kecil dari 0,05 . Sehingga dapat diambil hipotesis bahwa : "Benar terdapat pengaruh standarisasi ISO 9001:2008 terhadap kinerja karyawan"

Dan untuk menguji keberartian secara parsial pengaruh antara variabel budaya organisasi terhadap kinerja karyawan maka dilakukan uji hipotesis.

Rumusan hipotesisnya adalah :

$\mathrm{H} 0=$ diduga tidak terdapat pengaruh antara budayaorganisasi terhadap kinerja karyawan.

$\mathrm{Ha}=$ diduga terdapat pengaruh antara buda- ya organisasi terhadap kinerja karyawan.

Taraf signifikansinya adalah 5\% keputusan menerima atau menolak hipotesis yang diajukan dilakukan dengan syarat sebagai berikut: 
1) Jika Thitung $\leqslant$ Ttabel maka hipotesis nol (H0) diterima atau Ha ditolak. Artinya tidak terdapat pengaruh antara budaya organisasi terhadap kinerja karyawan.

2) Jika Thitung $\geqslant$ Ttabel maka hipotesis nol (H0) ditolak atau Ha diterima. Artinya terdapat pengaruh antara budaya organisasi terhadap kinerja karyawan.

Pada tabel 4.17 hasil output SPSS diperoleh Thitung sebesar -1,241 dan pada Ttabel nya 1,989. Maka -1,241 < dari 1,989. Artinya Thitung lebih kecil dari pada Ttabel sehingga hipotesis ditolak, dengan nilai probabilitas pada kolom signifikan sebesar 0,218 lebih besar dari 0,05. Sehingga dapat diambil hipotesis bahwa : "Tidak terdapat pengaruh antara budaya organisasi terhadap kinerja karyawan".

\section{Dengan Menggunakan Uji F}

Untuk mengetahui pengaruh secara simultan antara standarisasi ISO 9001:2008 dan budaya organisasi terhadap kinerja karyawan maka dilakukan uji hipotesis dengan membanding- kan nilai Fhitung dengan Ftabel ataupun dengan melihat angka signifikansinya (probabilitas).

Rumusan hipotesisnya adalah :

$\mathrm{HO}=$ diduga tidak terdapat pengaruh antara standarisasi ISO dan budaya organisasi terhadap kinerja karyawan.

$\mathrm{Ha}=$ diduga terdapat pengaruh antara stan- darisasi ISO 9001:2008 dan budaya organisasi terhadap kinerja karyawan.

Taraf signifikansinya adalah 5\% keputusan menerima atau menolak hipotesis yang diajukan dilakukan dengan syarat sebagai berikut:

a. Jika Fhitung $\leqslant$ Ftabel maka hipotesis nol (H0) diterima atau Ha ditolak artinya tidak terdapat pengaruh secara simultan antara standarisasi ISO 9001:2008 dan budaya organisasi terhadap kinerja karyawan.

b. Jika Fhitung $\geqslant$ Ftabel maka hipotesis nol (H0) ditolak atau Ha diterima artinya terdapat pengaruh secara simultan antara standari- sasi ISO 9001:2008 dan budaya organisasi terhadap kinerja karyawan.

\begin{tabular}{|c|c|c|c|c|c|c|}
\hline \multicolumn{7}{|c|}{ Tabel 4.17 $\underset{\text { ANOVA }}{\text { Hipotesis Uji }}$ F } \\
\hline \multicolumn{2}{|c|}{ Madel } & $\begin{array}{l}\text { Sum of } \\
\text { Squares }\end{array}$ & df & Mean Square & $\mathrm{F}$ & Sig. \\
\hline \multirow[t]{3}{*}{1} & Regression & 196.385 & 2 & \multirow{3}{*}{$\begin{array}{l}98.192 \\
19.629\end{array}$} & \multirow[t]{3}{*}{5.002} & \multirow[t]{3}{*}{$.009^{\mathrm{a}}$} \\
\hline & Residual & 1609.568 & 82 & & & \\
\hline & Total & 1805.953 & 84 & & & \\
\hline \multicolumn{7}{|c|}{ a. Predictors: (Constant), $\times 2, \times 1$} \\
\hline \multicolumn{7}{|c|}{ b. Dependent Variable: $Y$} \\
\hline
\end{tabular}

Fhitung yang diperoleh dari output SPSS pada gambar 4.12 adalah sebesar 5,002 dan F tabelnya adalah 3,11. Maka 5,002 > 3,11. Ar- tinya nilai Fhitung lebih besar dari nilai Ftabel, sehingga hipotesis diterima, dengan nilai probabilitas pada kolom signifikansi sebesar 0,009, jauh lebih kecil dari 0,05. Sehingga da- pat diambil hipotesis bahwa: "Benar terdapat pengaruh antara standarisasi ISO 9001:2008 dan budaya organisasi secara bersama-sama (simultan) terhadap kinerja karyawan".

\section{KESIMPULAN DAN SARAN}

\section{Kesimpulan}

Kesimpulan penelitian mengenai pengaruh standarisasi ISO 9001:2008 dan budaya organisasi terhadap kinerja karyawan pada PT. Sumberdaya Dian Mandiri adalah sebagai berikut :

a. Berdasarkan hasil analisa menunjukan, bahwa terdapat pengaruh positif antara standarisasi ISO 9001:2008 terhadap kinerja karyawan. Dengan nilai Thitung yang diperoleh dari hasil output SPSS pada variabel X1 adalah sebesar 3,056 dan pada Ttabel nya adalah 1,989 dan nilai probabilitas kolom signifikannya sebesar 0,003 . 
b. Berdasarkan hasil analisa menunjukan, bahwa tidak terdapat pengaruh positif antara budaya organisasi terhadap kinerja karyawan. Dengan nilai Thitung sebesar - 1,241 dan pada Ttabel nya 1,989 dan nilai probabilitas pada kolom signifikannya sebesar 0,218 .

c. Terdapat pengaruh yang positif dan signi- fikan antara standarisasi ISO 9001:2008 dan budaya organisasi secara simultan terhadap kinerja karyawan dengan tingkat hubungan rendah dimana nilai r2 (R Square) sebesar 10,9\%.

\section{Saran}

Melihat dari hasil penelitian yang telah dibuat maka peneliti ingin membarikan saran kepada perusahaan agar kinerja karyawan semakin meningkat agar dapat memajukan perusahaan diantaranya yaitu :

a. Mengadakan trainning ISO 9001:2008 secara merata pada seluruh karyawan agar pemahaman karyawan semakin luas mengenai pentingnya standarisasi ISO 9001:2008.

b. Peneliti juga menyarankan agar standarisasi ISO 9001:2008 terus dijadikan pedoman sistem mutu agar dapat mendukung pelak- sanaan kegiatan perusahaan yang bergerak dibidang jasa konsultan dan outsourching yang telah bekerja sama dengan perusahaan-perusahaan besar.

c. Diharapkan kedepannya penerapan budaya organisasi lebih ditingkatkan lagi agar benar-benar meresap dan pegawai mau memahami arti dari budaya organisasi.

d. Mengadakan trainning pelatihan keteram- pilan karyawan berkesinambungan dan merata agar kemampuan semua karyawan me- ningkat sehingga bisa berkontribusi dalam memajukan perusahaan.

\section{DAFTAR PUSTAKA}

Amrullah, Fikri,2015, Pengaruh Penerapan ISO 9001:2000 Dan Penerapan Audit Mutu Internal Terhadap Kinerja Organisasi Pada SAMSAT Kota Tangerang, Skripsi, Fakultas Ekonomi dan Bisnis,Universitas Islam Negeri Syarif Hidayatullah, Jakarta.

Berata, I Komang Oko, 2014, Panduan Praktis HRD \& GA, Cetakan Empat, Jakarta: Raih Asa Sukses

Dalimunthe, Asfhar Halim, 2009, Pengaruh Budaya Organisasi Terhadap Kinerja Karyawan Studi Kasus Pada Dinas Komunikasi Informasi dan Pengelo- laan Data Elektronik Kota Medan, Skripsi, Fakultas Ilmu Sosial dan Ilmu Politik, Universitas Sumatera Utara, Medan.

Hasib, Hasibuan S.P, Melayu, 2013, Manajemen Sumber Daya Manusia, Edisi Revisi, Jakarta: PT. Bumi Aksara.

Juana Priyantini ad al, Pengaruh Implementasi Sistem Manajemen Mutu ISO 9001: 2008 Terhadap Kinerja Pegawai Dengan Mediasi Kepuasan Kerja, Jurnal Buletin Ilmu Ekonomi Vol. 21 No. 1 Februari 2016

KiKiswanto, 2007, Implementasi Manajemen Kualitas dan Pengaruhnya Pada Kinerja Perusahaan Ditinjau Dari Sudut Pandang Total Quality ManajemenStudi Empiris Terhadap Manajer Perusahaan Manufaktur di Jawa Tengah, Tesis, Program Pasca Sarjana Sains Akuntansi, Universitas Diponegoro, Semarang

Lestari, Indriana, 2012, Pengaruh Sistem Penjaminan Mutu Internal Dan Sistem Manajemen Mutu ISO 9001:2008 Terhadap Kinerja Universitas Katolik Indonesia Atmajaya Jakarta, Tesis, Fakultas Ilmu Sosial dan Ilmu Politik, Program Pasca Sarjana, Universitas Indonesia, Jakarta Nasional, Badan Standarisasi, 2014, Pengantar Standarisasi, Edisi Kedua, Jakarta: BSN 
Pengaruh Standarisasi ISO 9001: 2008 dan Budaya Organisasi terhadap Kinerja Karyawan pada PT. Sumberdaya Dian Mandiri

Nasution, M. Nur, 2015, Manajemen Mutu Terpadu (Total Quality Manajemen), Edisi Ketiga, Bogor: Ghalia Indonesia

Nurlaela Wati, Lela, 2011, Modul Praktikum Statistik Terapan SPSS Versi 17, Jakarta

Peraturan Pemerintah Republik Indonesia, No. 102,2000, Standarisasi Nasional

Pratama, Yoga, 2012, Pengaruh Budaya Organisasi Terhadap Kinerja Pegawai Pada Kantor Kecamatan Nanggung Kebupaten Bogor, Skripsi, Program Sarjana, Fakultas Ilmu Sosial dan Ilmu Politik, Universitas Indonesia

Purba Debbie Tiur J ad al, Analisis Pengaruh Sistem Manajemen Mutu ISO 9001: 2008 Terhadap Kinerja Karyawan PT. X, e-Journal TeknikInsdustri FT USU Vol. 1 No. 1, Februari 2014.

Rangkuti, Freddy,2013, Customer Service Satisfaction \& Call Center Berdasar- kan ISO 9001, Jakarta: PT. Gramedia Pustaka Utama

Rivai, Veithzal dan Ella Jauvani Sagala, 2013, Manajemen Sumber Daya Manusia Untuk Perusahaan Dari Teori Ke Praktek, Edisi Kedua, Jakarta: PT. Raja Grafindo Persada

Sobirin, Achmad, 2009, Budaya Organisasi Pengertian, Makna, Dan Aplikasinya Dalam Kehidupan Organisasi, Edisi Kedua, Yogyakarta: Sekolah Tinggi Ilmu Manajemen YKPN

Sinaga, Prima Nugraha, Pengaruh Budaya Or- ganisasi Terhadap Kinerja Karyawan Pada Sekretariat Daerah

Kabupaten Dairi Sumatera Utara, Skripsi, Fakul- tas Ilmu Sosial dan Ilmu Politik, Uni- versitas Sumatera Utara, Medan

Sudaryono, 2014, Budaya \& Perilaku Orga- nisasi, Jakarta: Lentera Ilmu Cendekia

Supriyadi, Eko, 2012, Pengaruh Penerapan Sistem Manajemen Mutu Iso 9001 : 2008 Terhadap Kinerja Guru Di Smk Negeri 1 Sedayu Bantul, Skripsi, Fakultas Teknik, Universitas Negeri Yogyakarta, Yogyakarta

Suryatama, Erwin, 2014, Aplikasi ISO sebagai Standar Mutu, Cetakan Pertama, Jakarta: Kata Pena 